\title{
Effects of Power Lines on Area Use and Behaviour of Semi-Domestic Reindeer in Enclosures
}

\author{
K. Flydal, ${ }^{1}$ L. Korslund, ${ }^{2}$ E. Reimers, ${ }^{1}$ F. Johansen, ${ }^{1}$ and J. E. Colman ${ }^{1,3}$ \\ ${ }^{1}$ Department of Biology, University of Oslo, P.O. Box 1066 Blindern, 0316 Oslo, Norway \\ ${ }^{2}$ Department of Natural Sciences, University of Agder, 4604 Kristiansand, Norway \\ ${ }^{3}$ Department of Ecology and Natural Resource Management, Norwegian University of Life Sciences, P.O. Box 5003, 1432 Ås, Norway
}

Correspondence should be addressed to E. Reimers, eigil.reimers@bio.uio.no

Received 20 May 2009; Accepted 27 August 2009

Recommended by Jean Clobert

\begin{abstract}
We conducted large-scale, replicated experiments to test the effects of two parallel power lines on area use, behaviour, and activity of semidomestic reindeer in enclosures. Yearling female reindeer were released into four $50 \times 400 \mathrm{~m}$ enclosures; two treatment enclosures with power lines and two control enclosures. Reindeer from two herds, one from Kautokeino (domestic tame) and one from Vågå, (domestic wild) were tested separately and compared. Individual location within the enclosures was not affected by the power lines. Effects on restless behaviour were ambiguous, with slightly more restless behaviour in the treatment enclosures for the domestic tame reindeer, while the domestic wild reindeer maintained a stable level in the treatment enclosures, increasing with time in the control enclosures. Activity changes were slightly more common among animals within treatment enclosures for both herds, with no indication of habituation during the experiment. The domestic wild reindeer had more than three times the amount of restless behaviour than the domestic tame reindeer. Our study indicates that for reindeer in enclosures, the disturbance from a power line construction is negligible. This suggests that power lines are a minor disturbing factor compared to human handling when using fenced in areas like grazing gardens in reindeer husbandry.
\end{abstract}

Copyright $\odot 2009$ K. Flydal et al. This is an open access article distributed under the Creative Commons Attribution License, which permits unrestricted use, distribution, and reproduction in any medium, provided the original work is properly cited.

\section{Introduction}

Roads, railroads, power transmission lines, pipe lines and similar linear features that crisscross animal habitats, may cause aversion or stress because of disturbances associated with the linear object, such as noise or movement from vehicles and people $[1,2]$. Such features' visual appearance in the landscape may also influence animal movement if an animal perceives the feature as an obstacle, such as a fence or wall.

By 2004, there were almost $30000 \mathrm{~km}$ of high-voltage $(>33 \mathrm{kV})$ power lines in Norway, many of which transverse alpine regions inhabited by wild and semi-domestic reindeer (Rangifer tarandus tarandus). Presently, there are numerous plans for new large $(420 \mathrm{kV})$ and smaller power lines throughout reindeer areas in Scandinavia. Recent studies suggest that power lines affect reindeer area use, either by causing the animals to avoid areas adjacent to the lines or by hindering their movements under the lines and limiting access to pasture [3-7]. However, another study found no barrier or aversion effects from a power line in North Ottadalen on wild reindeer migration or grazing behaviour [8]. Similarly, no negative effects of power lines were found on the grazing activity of Cervidae in forested areas $[9,10]$, or on a variety of livestock [11], with one possible exception for cattle Bos taurus [12]. Nevertheless, wild reindeer management authorities are concerned that new power lines will be negative for reindeer populations in Norway.

In the reindeer husbandry industry, reindeer are gathered several times a year for handling, mostly in connection with branding or slaughtering. During a round-up, large groups of reindeer, or even the entire herd, will be herded into large enclosures called "grazing gardens" adjacent to the smaller corals, where smaller groups or individual reindeer are contained and man-handled. A majority of these activities are conducted in the vicinity of roads to facilitate access for the herdsmen. Power lines often cross or are located in the vicinity of grazing gardens and are claimed to disturb the animals and/or act as barriers for their movements. 
The purpose of this study was to investigate direct effects of power lines on the area use and behaviour of semidomesticated reindeer in four enclosures: two treatment enclosures with power lines, and two control enclosures with no power lines. If power lines were to have a disturbing effect on reindeer, we predicted the following

(1) less use of sections of the enclosures closest to the power lines leading to an uneven distribution in the treatment enclosures compared to the control enclosures,

(2) more restless behaviour, indicated by higher frequency of activity changes and more time spent on walking and running: (a) for reindeer when nearer the power lines in the treatment enclosures, and (b) in the treatment enclosures relative to the "control" enclosures,

(3) given an initial disturbance response, some form of habituation or sensitisation in the treatment enclosures.

\section{Material and Methods}

We carried out the experiment near the road through Slådalen in Lesja, southern Norway $\left(8^{\circ} 58^{\prime} \mathrm{E}, 62^{\circ} 4^{\prime} \mathrm{N}\right)$, in the eastern part of North Ottadalen wild reindeer area (Figure 1). Two parallel power lines of 132 and $300 \mathrm{kV}$ transect the area in a north-south direction. The study site is above the tree line in the low alpine region, approximately $1100 \mathrm{~m}$ a.s.l., and was chosen because of relatively flat topography, easy access, and uniform vegetation dominated by dwarf birch Betula spp., lichens Cladonia spp., and graminoids.

2.1. Study Design. We constructed four enclosures: two treatment enclosures underneath the power lines and two control enclosures (Figure 1). Each enclosure measured $50 \times$ $400 \mathrm{~m}$, and we recorded the position of individual reindeer within an enclosure by marking four $100 \mathrm{~m}$ zones, with the power lines passing across the uppermost zone of the treatment enclosures. We marked the borders with coloured tape strips along the height of the fence for easy identification of animal location in relation to zones. We used $1.60 \mathrm{~m}$ wire fencing, except where the fence passed under the power lines $( \pm 25 \mathrm{~m})$. Here we replaced the wire fence with a wooden fence to prevent electrical discharge. We placed drinking stations, with a $50 \mathrm{~L}$ water bucket filled every second day, next to the fence in the middle of zones 1 and 4 in all enclosures. Because the animals foraged on natural vegetation, specifically dwarf birch (Betula nana) and lichens (Cladonia sps and Cladina sps) additional fodder was not necessary. We placed a $5 \mathrm{~m}$ high observation tower with room for one observer at the same position outside each enclosure in order to minimize the confounding effect of the observers. The chosen position, $50 \mathrm{~m}$ from the line between zone 1 and 2, was the only one giving full visibility of the entire area of each enclosure. The topography and distance between enclosures prevented visual and audible contact between reindeer from one enclosure to another. The power lines followed the top of a ridge, and we positioned the enclosures at right angles to the ridge. The power lines were visible for the reindeer from anywhere within the two experimental enclosures, and the layout allowed for similar habitat conditions in the different enclosures (Figure 1). In order to check for possible differences in vegetation, we recorded the $\%$ coverage of all plant species in 12 randomised $1 \times 1 \mathrm{~m}$ plots in all zones for each enclosure, that is, a total of 192 plots.

Because the behaviour repertoire of reindeer in terms of their response towards disturbances can differ amongst different herds [13], we used reindeer of two different origins to increase the applicability of our results. The experiment was therefore divided into two trials, one for each type of reindeer. In trial one (25 August-5 September 1999; 12 days), we used domestic reindeer from Kautokeino, Finnmark county, that had previously been kept in enclosures and were relatively tame (from now on called "domestic tame"). In trial two (6-13 September 1999; 8 days), we used domestic reindeer from Våga tamreinlag, Oppland county, that had been free ranging and came directly from mountain grazing (from now on called "domestic wild"). For each trial, we released three 15-16-months old female reindeer into each of the enclosures. A number of three reindeer per enclosure were chosen based on the area and pasture conditions inside each enclosure. This made additional fodder unnecessary, making the grazing behaviour comparable to natural conditions. Females were chosen because they are considered to be more sensitive to disturbances than males $[14,15]$ and if power lines have behavioural effects on reindeer, females are most likely to reveal such effects. Yearlings were chosen because they are in their first independent (in relation to mother) year and have had no or little previous exposure to power lines (or other infrastructure). With our restricted sample size they made up a homogenous group in relation to age and previous experience. No measurable effect on yearling females would imply that effects on males and older females are most likely negligible.

All animals used for the experiment were healthy, and they remained so without any sign of disease or injury throughout the trials. Upon arrival, the animals were retrieved from the transporting truck individually and assigned enclosures randomly. After the experiment, the animals were returned to their herds in the same transporting truck.

Wind speed $(\mathrm{m} / \mathrm{s})$, temperature $\left({ }^{\circ} \mathrm{C}\right)$, relative humidity $(\%)$, and precipitation $(\mathrm{mm})$ were automatically recorded every 10 minutes at a portable Grant Squirrel weather station (Mini-Met automatic weather station, Omni Instruments, Ireland) placed between the enclosures. Data on power line transmission load (MW) every hour were provided by Statnett SF.

2.2. Observations. At the start of each trial, three female reindeer were released into each of the randomly assigned enclosures and allowed 12 hours to normalize and adjust before observations began. 


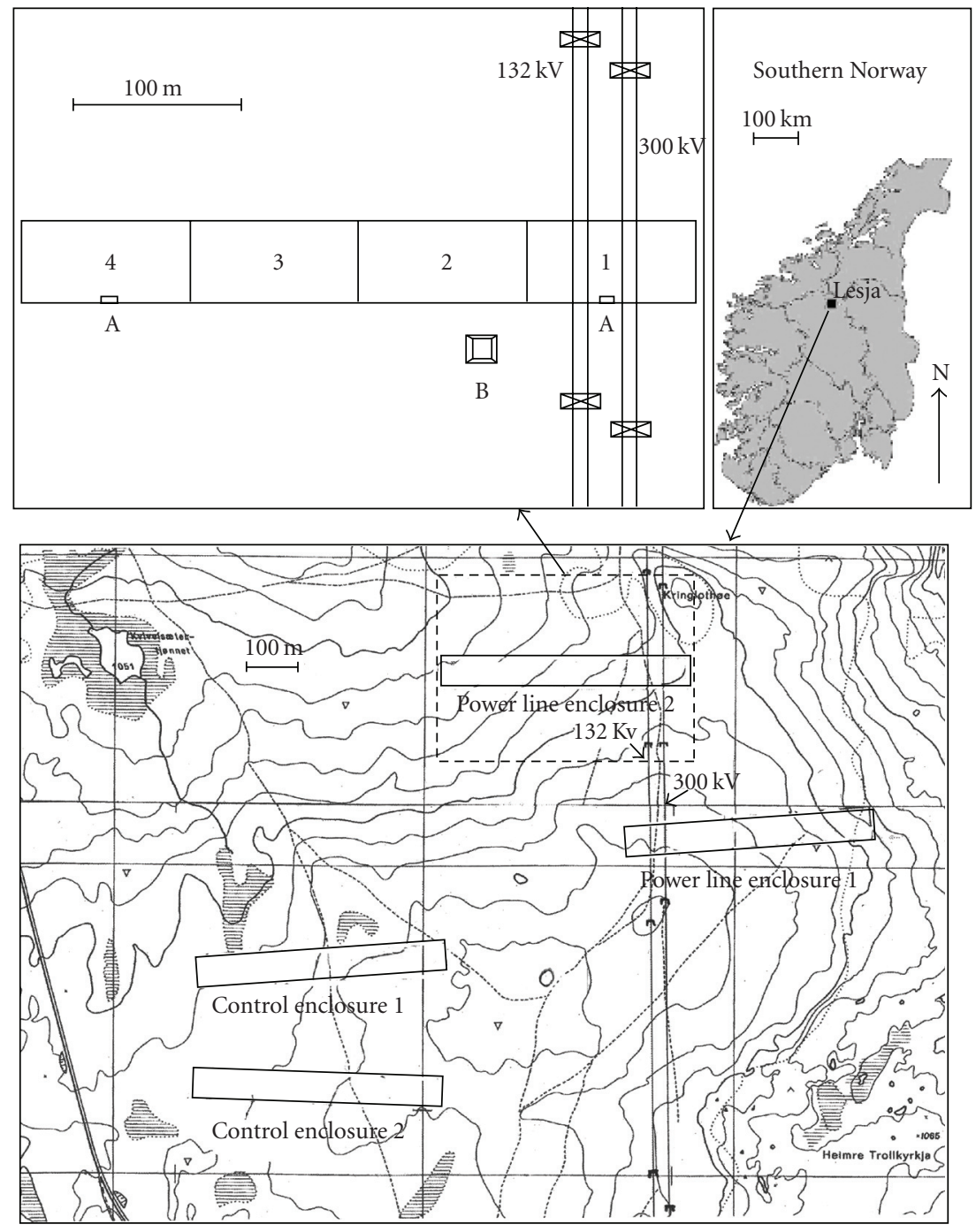

FIGURE 1: Location of the study area in Southern Norway and the location of the power lines and the four enclosures. The illustration of one of the enclosures shows the four $100 \mathrm{~m}$ zones: (A) the placement of drinking stations, and (B) the observation tower.

The animals' behaviour and positions were recorded from the towers using telescopes, stop-watches with timesplit, and dictaphones. All four enclosures were observed simultaneously.

An observer was randomly assigned to an enclosure and usually worked in three-hour shifts, with a one-hour break between shifts. After each break the observers were randomly assigned to another enclosure. Animals in all enclosures were observed simultaneously during both trials in order to cover all hours during daylight between 6 AM to 23 PM (see Figure 5). Reindeer activity and area use in the enclosures were measured using scan and focal animal sampling $[1,16$, 17]. Scan observations were performed every 10 minutes by simultaneously observing the three animals and recording their individual behaviour and position as explained in Colman et al. [18] and Colman et al. [19]. During feeding bouts, a focal was performed every twenty minutes by randomly choosing and observing one animal closely for 5 minutes. Animals wore coloured ear tags and the focal animal was drawn from a collection of colour samples. Animal behaviour and position was categorised into 7 types: feeding still, feeding slow walk, standing, lying head down, lying head up, walking, and running. We used specific measurements for each behaviour category to avoid potential overlap between similar behaviours such as, for example, trotting and running $[18,19]$. To further insure unbiased behavioural registrations, all observers conducted test trials together as a group to ensure similar observation techniques.

2.3. Statistical Analyses. We performed a detrended correspondence analysis (DCA) of vegetation cover of plant species in the zones of the four enclosures in CANOCO $[20,21]$.

Data from domestic tame and domestic wild animals were analysed separately because the two experimental trials were not performed simultaneously and, consequently, the ranges of covariates were not similar (especially for 
TAble 1: Minimum, median, and maximum of the covariate variables included in model testing.

\begin{tabular}{lcc}
\hline & Domestic tame & Domestic wild \\
\hline Precipitation $(\mathrm{mm} / \mathrm{h})$ & $0-0-4$ & $0-0-0$ \\
Relative humidity $(\%)$ & $5.5-10.9-16.7$ & $5.9-10.2-15.5$ \\
Wind speed $(\mathrm{m} / \mathrm{s})$ & $0.4-5.5-18.7$ & $0.8-6.5-14.0$ \\
Temperature $\left({ }^{\circ} \mathrm{C}\right)$ & $0.9-10.5-19.4$ & $5.4-10.4-18.2$ \\
Transmission load $(\mathrm{MW})$ & $0-80-246$ & $0-11-129$ \\
\hline
\end{tabular}

transmission load and wind speed, see Table 1). Precipitation was measured but was not included in the analyses since the amounts (number of days and $\mathrm{mm}$ received) were too small to test for any possible effects (Table 1). To account for potential bias in the data set due to repeated measurements of individuals we tested whether to include a random intercept-term for individuals within enclosures and enclosures within treatment levels in the models [22]. In addition, we tested whether to include a random intercept term for observer to account for any observer bias. Fitting the random interaction terms was based on AIC differences [23]. For all analyses, the inclusions of a random intercept term for individual animal and observer, but not enclosure, were supported $(\triangle \mathrm{AIC}>4)$. To be able to fit models with both fixed and random effects we used the generalized linear mixed models (glmer) framework of library lme 4 (http://lme4.r-forge.r-project.org/) in $\mathrm{R}[24,25]$. For each response variable the best model was found by selection among a set of a priori candidate models (Tables 5-10), based on the AIC criterion [26], and model fit was assessed graphically and numerically [23]. Treatment, as a predictor variable, was included in all models, except the null-model, to estimate its effect.

Analysis of animal space use was based on scan observations. Although reindeer are known to prefer staying together in groups, the three animals were frequently located in different parts of the enclosures. In addition, individual differences were corrected for by individual intercepts (see fitting random variables above). Therefore individual, rather than group, was the appropriate statistical unit. Since the glmer framework does not allow for a multinomial response variable, the response variable — animal location-was transformed into a binomial distribution by collapsing two and two zones into an upper and a lower half of the enclosure. We tested the probability of an animal being located in the lower half of the enclosure. Treatment, time (days after initiation), transmission load, and the two latter covariates' interaction with treatment were tested. Temperature was not expected to affect space use, but rather activity due to insect harassment (see below), and thus temperature was not included in any of the models. Relative humidity showed a strong negative correlation with temperature $(r=$ -0.48 and -0.44 for the two trials, resp.), and consequently this variable was neither included in any models. Because reindeer are known to prefer tracking into the wind [27], wind direction might affect area use. However, this is likely to be important for reindeer only at a much larger scale and not in pens and enclosures [28, 29]. In addition, during both experimental trials, the prevailing wind was mostly southerly (average bearing of wind: $211 \pm 3,52$ and $209 \pm 2,33$, for the first and second trial, resp.), that is, perpendicular to the enclosures, and hence should not interfere with animal location. Consequently we expected wind direction to have a negligible effect on position.

Analysis of activity changes was based on focal observations. Number of activity changes $\min ^{-1}$ was used as response variable in the analyses of mixed log-linear models. An activity change was defined as a change to another behaviour type which then had to last for more than $5 \mathrm{sec}-$ onds. Treatment, as well as the covariates time, temperature, wind speed, relative humidity, transmission load, and all interactions with treatment were tested. Wind speed, relative humidity, and transmission load were especially interesting when interacting with treatment because wind speed can result in turbulent noise from masts, humidity might affect corona noise from lines, and transmission load potentially affects animals in the close (within ca. $50 \mathrm{~m}$ ) vicinity of the power lines. Temperature data were included because some incidents of insect harassment were observed during the experiment, and insect activity is strongly dependent on temperature $[17,30]$. Since an animal easily could move between zones during a 5-minute focal observation, a predictor variable representing the animal's position during the focal observation was calculated. This predictor variable represents the potential exposure to the upper part of the enclosure (and thus the power lines of the treatment enclosures). The predictor was defined as the mean zone number, weighted with respect to the time spent in each zone:

$$
\frac{\sum\left(t_{\text {zone }} \times \text { no }_{\text {zone }}\right)}{t_{\text {total }}},
$$

where $t_{\text {zone }}$ is the time in seconds spent in a zone, no zone $_{\text {is }}$ the number of the zone (1-4), and $t_{\text {total }}$ is the total time in seconds of the specific focal observation (usually, but not always 300). This resulted in position being a continuous variable between 1.0 and 4.0 .

Analysis of restless behaviour was based on scan observations. Restless behaviour was defined as when the observed individuals were performing one of the following activities: "running", "walking," or "standing", and was treated as a binomial response variable. The proportion of observations in which the animal was engaged in restless behaviour was analyzed with mixed logistic models. Since both activity changes and restless behaviour are expected to reflect animal discomfort, the predictor variables tested here were the same as when investigating activity changes. However, here the animal's exact position was used, rather than the calculated predictor shown above, since the scan observation provides an instant observation of position.

\section{Results}

3.1. General. The vegetation in the four zones for each enclosure along the axes of the two DCA ordination gradients with the highest explanatory power showed high similarity between all zones, with a possible exception for zone 3 
TABLE 2: Results from the best mixed logistic regression model of proportion restless behaviour of two trials with 12 domestic reindeer each. Animals of different degree of tameness were tested separately. Intercept in all models is the estimate for zone 1 in a control enclosure. The model uses a logit-link.

\begin{tabular}{|c|c|c|c|c|}
\hline Parameter & $\mathrm{b}$ & SE & $\mathrm{T}$ & $P$ \\
\hline \multicolumn{5}{|l|}{ Domestic tame $(n=4824)$} \\
\hline Intercept & -3.6293 & 0.3926 & -9.244 & $<.001$ \\
\hline Treatment & -0.7618 & 0.2640 & -2.886 & .004 \\
\hline Zone (2 versus 1 ) & -0.0819 & 0.1742 & -0.470 & .638 \\
\hline Zone (3 versus 1 ) & -0.4148 & 0.1806 & -2.297 & .022 \\
\hline Zone (4 versus 1 ) & -0.5606 & 0.1590 & -3.527 & $<.001$ \\
\hline Day & -0.0493 & 0.0249 & -1.978 & .048 \\
\hline Temperature $\left({ }^{\circ} \mathrm{C}\right)$ & 0.1621 & 0.0189 & 8.558 & $<.001$ \\
\hline Transmission load (MW) & 0.0041 & 0.0011 & 3.850 & $<.001$ \\
\hline Wind speed $(\mathrm{m} / \mathrm{s})$ & -0.1460 & 0.0348 & -4.192 & $<.001$ \\
\hline Treatment $\times$ Wind speed & 0.1553 & 0.0409 & 3.797 & $<.001$ \\
\hline \multicolumn{5}{|l|}{ Domestic wild $(n=3429)$} \\
\hline Intercept & -1.4680 & 0.3260 & -4.504 & $<.001$ \\
\hline Treatment & 1.0755 & 0.3763 & 2.859 & .004 \\
\hline Zone (2 versus 1 ) & -0.1724 & 0.1132 & -1.524 & .128 \\
\hline Zone (3 versus 1 ) & -0.3503 & 0.1171 & -2.992 & .002 \\
\hline Zone (4 versus 1 ) & -0.4853 & 0.1119 & -4.336 & $<.001$ \\
\hline Wind speed $(\mathrm{m} / \mathrm{s})$ & -0.0315 & 0.0133 & -2.373 & .018 \\
\hline Day & 0.1176 & 0.0279 & 4.213 & $<.001$ \\
\hline Treatment $\times$ Day & -0.1192 & 0.0394 & -3.028 & .002 \\
\hline
\end{tabular}

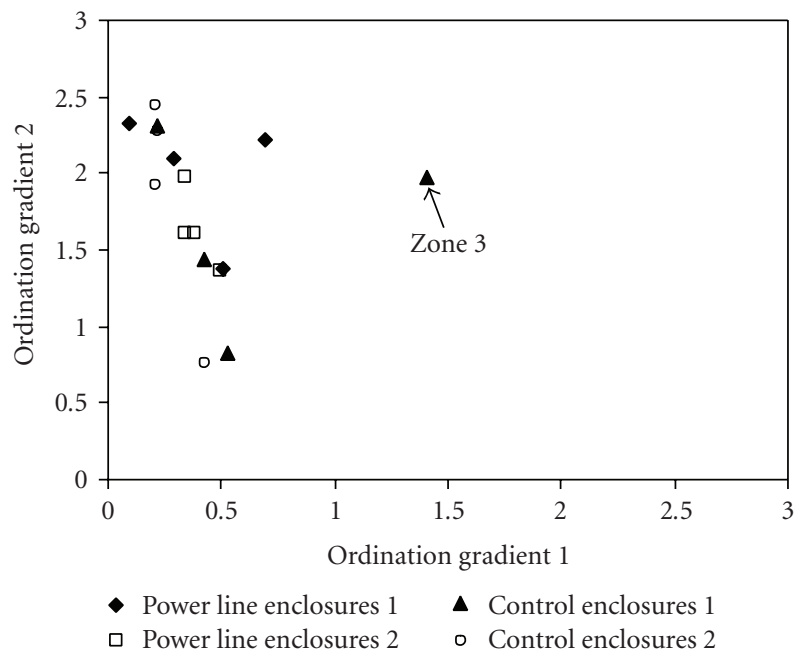

FIGURE 2: Plot of the four zones of the four enclosures (Power line 1 and 2, and Control 1 and 2) along the two ordination gradients with the highest explanatory power in a detrended correspondence analysis of plant species cover. All zones have similar vegetation, with a possible exception for zone 3 in control enclosure 1 .

in control enclosure 1 (Figure 2). This was the only zone out of the total 16 zones with some elements of marsh dominated vegetation. From this, we concluded that the variation in vegetation cover among zones was too small to have significant effects on reindeer behaviour and area use.
3.2. Restless Behaviour. The preferred model (model 30, Table 5) illustrates that the domestic tame animals showed a slightly higher level of restless behaviour within treatment enclosures compared to within control enclosures (Figure 3, Table 2). In addition, restless behaviour increased somewhat with an animal's decreasing distance to the upper part of the enclosure (towards the power line and/or the observation towers). The animals showed overall a slight, and only marginally significant, decrease in restless behaviour over time, in both treatment and control enclosures (Figure 3, Table 2). Further, the animals showed a general increase in restless behaviour as ambient temperature increased (a 15fold increase going from 0 to $18^{\circ} \mathrm{C}$ ), and this was also the case when the transmission load of the power lines increased (a 2.5-fold increase going from 0 to $250 \mathrm{MW}$ ). A significant interaction between treatment and wind speed indicates that while animals in control enclosures showed a decrease in restless behaviour as wind speed increased (90\% decrease going from 0 to $15 \mathrm{~m} / \mathrm{s}$ ), there was no such pattern among treatment animals (Table 2). Another model (model 33 Table 5) had a slightly better fit but was higher parameterized and therefore dismissed based on parsimony [31].

Overall, the domestic wild reindeer showed approximately three times more restless behaviour than the domestic tame reindeer (Figure 3 ). The domestic wild reindeer also showed a similar increase in restless behaviour with decreasing distance to the upper part of the enclosure in both treatment and control enclosures (Figure 3, Table 2). The model selection did not support a simple additive difference between treatments if the time interaction was left out 
TABLE 3: Results from the best mixed log-linear model of number of activity changes/minute of two trials with 12 domestic reindeer each. Animals of different degree of tameness were tested separately. Intercept in all models is the estimate for zone 1 in a control enclosure. The model uses a log-link; so effects must be summed and exponentiated to make predictions.

\begin{tabular}{|c|c|c|c|c|}
\hline Parameter & $\mathrm{b}$ & SE & $\mathrm{T}$ & $P$ \\
\hline \multicolumn{5}{|c|}{ Domestic tame $(n=391)$} \\
\hline Intercept & 0.0963 & 0.1474 & 0.653 & .513 \\
\hline Treatment & 0.1938 & 0.1045 & 1.853 & .063 \\
\hline \multicolumn{5}{|c|}{ Domestic wild $(n=347)$} \\
\hline Intercept & 1.3019 & 0.2728 & 4.772 & $<.001$ \\
\hline Treatment & 0.1607 & 0.0957 & 1.680 & .093 \\
\hline Position $^{(a)}$ & -0.1172 & 0.0427 & -2.743 & .006 \\
\hline Temperature $\left({ }^{\circ} \mathrm{C}\right)$ & -0.0809 & 0.0186 & -4.336 & $<.001$ \\
\hline
\end{tabular}

${ }^{(a)}$ Here position is a continuous measure (between 1.0 and 4.0) based on individual space distribution (relative time spent in each of the four zones) during a focal observation period (see methods).

TABLE 4: Results from the best mixed logistic regression model of position (proportion of observations when an animal is in the lower half of the enclosure (zones 3 and 4)) of two trials with 12 domestic reindeer each. Animals of different degrees of tameness were tested separately. Intercept in all models is the estimate for zone 1 in a control enclosure. The model uses a logit-link.

\begin{tabular}{|c|c|c|c|c|}
\hline Parameter & $\mathrm{b}$ & SE & $\mathrm{T}$ & $P$ \\
\hline \multicolumn{5}{|l|}{ Domestic tame $(n=4824)$} \\
\hline Intercept & 1.6953 & 0.2759 & 6.144 & $<.001$ \\
\hline Treatment & -1.1977 & 0.2400 & -4.99 & $<.001$ \\
\hline Transmission load (MW) & -0.0035 & 0.0005 & -6.657 & $<.001$ \\
\hline Day & -0.1262 & 0.0177 & -7.127 & $<.001$ \\
\hline Treatment $\times$ Day & 0.1212 & 0.0209 & 5.807 & $<.001$ \\
\hline \multicolumn{5}{|l|}{ Domestic wild $(n=3429)$} \\
\hline Intercept & 1.9107 & 0.4332 & 4.411 & $<.001$ \\
\hline Treatment & 1.7660 & 0.4210 & 4.195 & $<.001$ \\
\hline Day & -0.1575 & 0.0259 & -6.080 & $<.001$ \\
\hline Treatment $\times$ Day & -0.2359 & 0.0385 & -6.121 & $<.001$ \\
\hline
\end{tabular}

(model 1 versus models 2 and 9, Table 6). While treatment animals showed a stable high level of restless behaviour throughout the duration of the experiment, the control animals showed a strong increase in restless behaviour with time (Figure 3, Table 2). Both control and treatment animals showed a slight reduction in restless behaviour as wind speed increased (a $30 \%$ decrease going from 0 to $15 \mathrm{~m} / \mathrm{s}$ ).

3.3. Activity Changes. The model selection for activity changes of domestic tame reindeer showed that several models performed almost equally well (Table 7: 9 models differed by less than two AIC units). Among these models, the most parsimonious (model 2) indicated only a minor, and nonsignificant, effect of the treatment, as animals within treatment enclosures overall engaged in slightly more activity changes than animals within control enclosures (Table 3 ).

Also for rate of activity changes among domestic wild reindeer, the model selection revealed that several models came close to being best (Table 8: models 16, 20 and 24-26 differed by less than two AIC units). The most parsimonious (model 16) showed that, among the domestic wild reindeer, the rates of activity changes within treatment enclosures were not significantly more common, and that the domestic wild reindeer changed activities approximately three times more often than domestic tame (Table 3 ). The rate of activity changes, in both control and treatment enclosures, decreased as the animals moved away from the power line and the observation towers (Table 3). The animals decreased their rate of activity changes as temperature increased (a 75\% decrease going from 0 to $18^{\circ} \mathrm{C}$ ).

3.4. Space Use. The model selection of space use of domestic tame reindeer showed that two models performed almost equally well (Table 9: models 6 and 8 differed by less than two AIC units). The best model, based on parsimony, (model 6) showed that while treatment animals were found equally often in both the upper and lower half of the enclosure throughout the whole duration of the experimental trial, control animals most often used the lower half of the enclosure in the first days, but ended up using both halves equally over time (Figure 4, Table 4). The animals tended to move farther away from the upper parts of the enclosure as transmission load of the power lines decreased (as transmission load approached zero, $75 \%$ of observations were in the lower half, while at maximum recorded transmission load, the observations were divided equally between upper and lower half of the enclosure), and this pattern was oddly enough equally strong for both control and treatment 


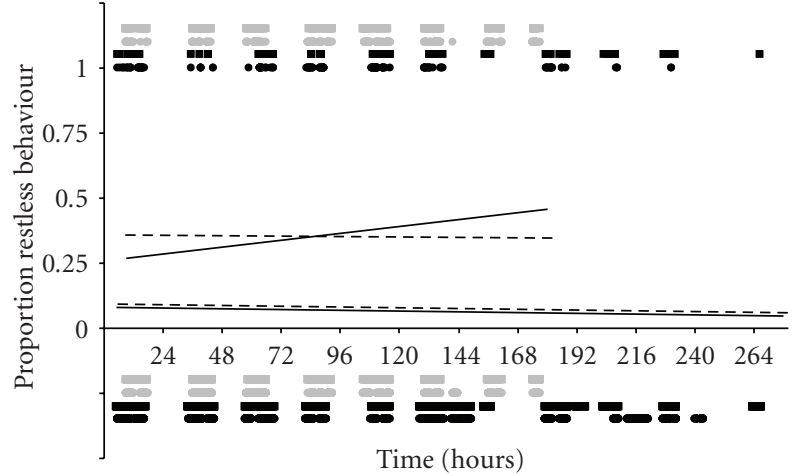

FIGURE 3: Observed activities and predicted proportions of restless behaviour over time (hours after the start of the experiment) among treatment and control reindeer from two source populations: domestic tame (Finnmark) and domestic wild (Vågå). Lines represent the estimates from zone 1 (the model intercept). Dashed and solid lines represent treatment animals and control animals, respectively. The two lower lines represent domestic tame animals, while the two upper represent domestic wild. The distributions of observations of restless and nonrestless behaviour are shown as symbols at the top and at the bottom, respectively. Black and grey symbols represent domestic tame and domestic wild, respectively. Circles and squares represent control and treatment animals, respectively.

animals since an interaction term with treatment was not supported.

The model selection of space use for domestic wild reindeer showed that two models came close to being the best (Table 10: models 6 and 8 differed by less than two AIC units). Model 8, the more parsimonious of the two, showed that the domestic wild reindeer overall stayed more in the lower part of the enclosure compared to domestic tame reindeer (Figure 4, Table 4). Treatment animals almost exclusively used the lower part of the enclosure in the start of the trial but increased their use of the upper section towards the end of the trial (Figure 4, Table 4). The control animals showed a similar, but less pronounced, trend in which the upper part of the enclosure was somewhat more used throughout the duration of the experimental trial.

\section{Discussion}

4.1. Effects of the Power Lines on Reindeer Area Use. The enclosure dimension of $50 \times 400 \mathrm{~m}$ was designed to provide an eventual gradient in the treatment enclosures with decreasing effect of the power lines at increasing distances away from them. If the power lines were to have any initial disturbing effect on reindeer, we expected to see some form of habituation among the treatment animals from start to finish of each trial. All animals, except the domestic tame animals from the treatment enclosures, tended to use the lower half of the enclosure predominantly in the early stages of the experimental trials and gradually used more of the upper parts as the trials progressed (Figure 3 ). The domestic tame treatment animals, however, used the two halves equally

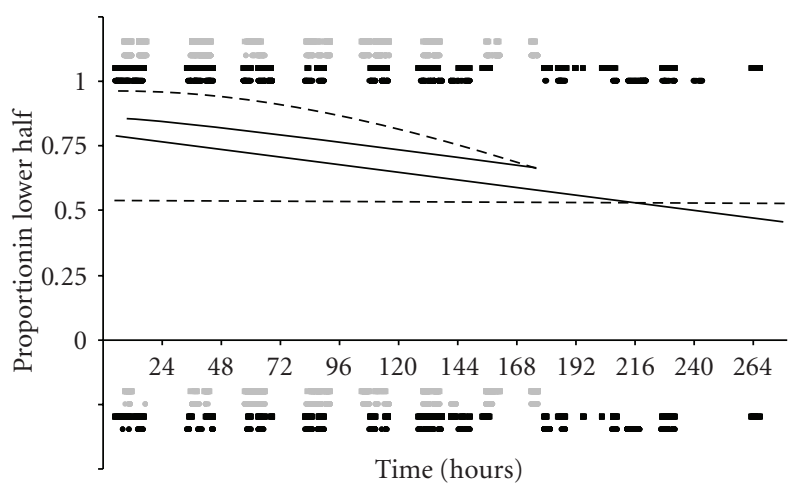

FIGURE 4: Observed positions and predicted use of lower half of the enclosure over time (hours after the start of the experiment) among treatment and control reindeer from two sources: domestic tame (Finnmark) and domestic wild (Vågå). A higher value illustrates more frequent use of the lower part of the enclosure. Lines represent the estimates from zone 1 (the model intercept). Dashed and solid lines represent treatment and control animals, respectively. The two lower lines represent domestic tame animals, while the two upper represent domestic wild. The distributions of observations of animals being located in the lower and upper part of the enclosure are shown as symbols at the top and at the bottom, respectively. Black and grey symbols represent domestic tame and domestic wild, respectively. Circles and squares represent control and treatment animals, respectively.

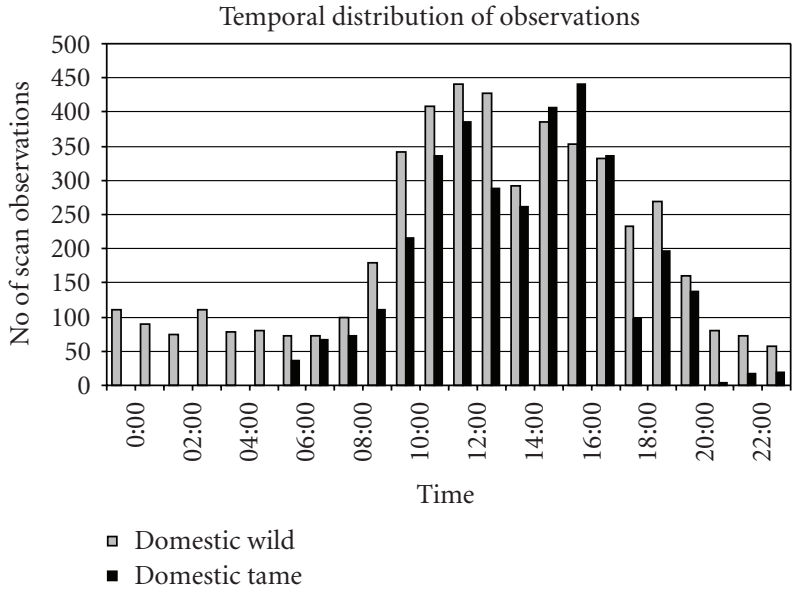

FIGURE 5: Number of scan observations from the two trials divided into hours.

throughout the study period. Since the control animals proved to be equally, if not more, reluctant to use the upper parts of the enclosures in the beginning of the experiments, it is likely that the observed changes in area use were related to a habituation towards the observer in the observation tower located at zone 2 (Figure 1) rather than the power lines itself. This is almost certainly the case for the control animals, and therefore, most plausible for the experimental animals as well.

4.2. Effects of the Power Lines on Reindeer Behaviour. It is vital for reindeer to optimise time spent feeding, resting, and 
TABLe 5: Results from model selection on restless behaviour among domestic tame animals using the AIC criterion (Np is number of parameters).

\begin{tabular}{|c|c|c|c|c|c|c|c|c|c|c|c|c|c|c|c|c|}
\hline $\begin{array}{l}\bar{\Xi} \\
\bar{\Sigma}\end{array}$ & 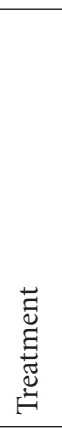 & ڤ્ञ & 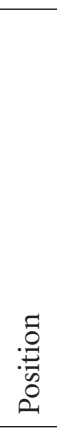 & 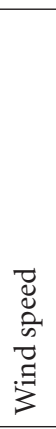 & 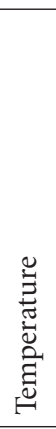 & 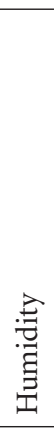 & 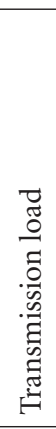 & 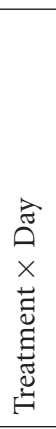 & 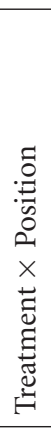 & 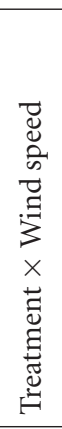 & 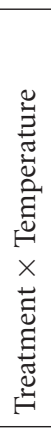 & 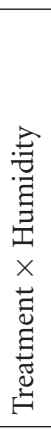 & 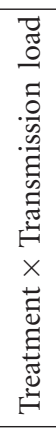 & $\mathrm{Np}$ & $\triangle \mathrm{AIC}$ & AIC weight \\
\hline 1 & & & & & & & & & & & & & & 3 & 114.1 & 0.00000 \\
\hline 2 & $\mathrm{x}$ & & & & & & & & & & & & & 4 & 115.4 & 0.00000 \\
\hline 3 & $\mathrm{x}$ & $\mathrm{x}$ & & & & & & & & & & & & 5 & 109.9 & 0.00000 \\
\hline 4 & $\mathrm{x}$ & & $\mathrm{x}$ & & & & & & & & & & & 8 & 100.1 & 0.00000 \\
\hline 5 & $\mathrm{x}$ & & & $\mathrm{x}$ & & & & & & & & & & 5 & 117.1 & 0.00000 \\
\hline 6 & $\mathrm{x}$ & & & & $\mathrm{x}$ & & & & & & & & & 5 & 60.90 & 0.00000 \\
\hline 7 & $\mathrm{x}$ & & & & & $\mathrm{x}$ & & & & & & & & 5 & 87.30 & 0.00000 \\
\hline 8 & $\mathrm{x}$ & & & & & & $\mathrm{x}$ & & & & & & & 5 & 105.4 & 0.00000 \\
\hline 9 & $\mathrm{x}$ & $\mathrm{x}$ & & & & & & $\mathrm{x}$ & & & & & & 6 & 106.6 & 0.00000 \\
\hline 10 & $\mathrm{x}$ & & $\mathrm{x}$ & & & & & & $\mathrm{x}$ & & & & & 10 & 105.9 & 0.00000 \\
\hline 11 & $\mathrm{x}$ & & & $\mathrm{x}$ & & & & & & $\mathrm{x}$ & & & & 6 & 107.4 & 0.00000 \\
\hline 12 & $\mathrm{x}$ & & & & $\mathrm{x}$ & & & & & & $\mathrm{x}$ & & & 6 & 62.40 & 0.00000 \\
\hline 13 & $\mathrm{x}$ & & & & & $\mathrm{x}$ & & & & & & $\mathrm{x}$ & & 6 & 85.20 & 0.00000 \\
\hline 14 & $\mathrm{x}$ & & & & & & $\mathrm{x}$ & & & & & & $\mathrm{x}$ & 6 & 106.4 & 0.00000 \\
\hline 15 & $\mathrm{x}$ & $\mathrm{x}$ & & & $\mathrm{x}$ & & & & & & & & & 6 & 44.50 & 0.00000 \\
\hline 16 & $\mathrm{x}$ & & $\mathrm{x}$ & & $\mathrm{x}$ & & & & & & & & & 8 & 51.30 & 0.00000 \\
\hline 17 & $\mathrm{x}$ & & & $\mathrm{x}$ & $\mathrm{x}$ & & & & & & & & & 6 & 49.60 & 0.00000 \\
\hline 18 & $\mathrm{x}$ & & & & $\mathrm{x}$ & $\mathrm{x}$ & & & & & & & & 6 & 58.70 & 0.00000 \\
\hline 19 & $\mathrm{x}$ & & & & $\mathrm{x}$ & & $\mathrm{x}$ & & & & & & & 6 & 28.60 & 0.00000 \\
\hline 20 & $\mathrm{x}$ & $\mathrm{x}$ & & & $\mathrm{x}$ & & $\mathrm{x}$ & & & & & & & 7 & 25.50 & 0.00000 \\
\hline 21 & $\mathrm{x}$ & & $\mathrm{x}$ & & $\mathrm{x}$ & & $\mathrm{x}$ & & & & & & & 9 & 22.90 & 0.00001 \\
\hline 22 & $\mathrm{x}$ & & & $\mathrm{x}$ & $\mathrm{x}$ & & $\mathrm{x}$ & & & & & & & 7 & 22.90 & 0.00001 \\
\hline 23 & $\mathrm{x}$ & & & & $\mathrm{x}$ & $\mathrm{x}$ & $\mathrm{x}$ & & & & & & & 7 & 30.50 & 0.00000 \\
\hline 24 & $\mathrm{x}$ & $\mathrm{x}$ & & $\mathrm{x}$ & $\mathrm{x}$ & & $\mathrm{x}$ & & & & & & & 10 & 22.20 & 0.00001 \\
\hline 25 & $\mathrm{x}$ & & $\mathrm{x}$ & $\mathrm{x}$ & $\mathrm{x}$ & & $\mathrm{x}$ & & & & & & & 8 & 16.20 & 0.00016 \\
\hline 26 & $\mathrm{x}$ & $\mathrm{x}$ & $\mathrm{x}$ & $\mathrm{x}$ & $\mathrm{x}$ & & $\mathrm{x}$ & & & & & & & 11 & 14.20 & 0.00045 \\
\hline 27 & $\mathrm{x}$ & $\mathrm{x}$ & $\mathrm{x}$ & $\mathrm{x}$ & $\mathrm{x}$ & $\mathrm{x}$ & $\mathrm{x}$ & & & & & & & 12 & 16.20 & 0.00016 \\
\hline 28 & $\mathrm{x}$ & $\mathrm{x}$ & $\mathrm{x}$ & $\mathrm{x}$ & $\mathrm{x}$ & & $\mathrm{x}$ & $\mathrm{x}$ & & & & & & 12 & 7.400 & 0.01335 \\
\hline 29 & $\mathrm{x}$ & $\mathrm{x}$ & $\mathrm{x}$ & $\mathrm{x}$ & $\mathrm{x}$ & & $\mathrm{x}$ & & $\mathrm{x}$ & & & & & 14 & 20.20 & 0.00002 \\
\hline 30 & $\mathrm{x}$ & $\mathrm{x}$ & $\mathrm{x}$ & $\mathrm{x}$ & $\mathrm{x}$ & & $\mathrm{x}$ & & & $\mathrm{x}$ & & & & 12 & 1.300 & 0.28194 \\
\hline 31 & $\mathrm{x}$ & $\mathrm{x}$ & $\mathrm{x}$ & $\mathrm{x}$ & $\mathrm{x}$ & & $\mathrm{x}$ & & & & $\mathrm{x}$ & & & 12 & 16.20 & 0.00016 \\
\hline 32 & $\mathrm{x}$ & $\mathrm{x}$ & $\mathrm{x}$ & $\mathrm{x}$ & $\mathrm{x}$ & & $\mathrm{x}$ & & & & & & $\mathrm{x}$ & 12 & 12.60 & 0.00099 \\
\hline 33 & $\mathrm{x}$ & $\mathrm{x}$ & $\mathrm{x}$ & $\mathrm{x}$ & $\mathrm{x}$ & & $\mathrm{x}$ & $\mathrm{x}$ & & $\mathrm{x}$ & & & & 13 & 0.000 & 0.54007 \\
\hline 34 & $\mathrm{x}$ & $\mathrm{x}$ & $\mathrm{x}$ & $\mathrm{x}$ & $\mathrm{x}$ & & $\mathrm{x}$ & & & $\mathrm{x}$ & & & $\mathrm{x}$ & 13 & 2.400 & 0.16267 \\
\hline
\end{tabular}

ruminating in order to procure and maintain energy reserves $[19,28,32,33]$. This is especially important during stressful periods when the animals are exerting themselves such as during calving and the rut, and during herding, roundups, and handling for domestic reindeer. Disturbances may negatively affect an optimal energy budget by increasing the time spent on restless behaviour $[34,35]$ or leading to the avoidance of preferred pastures. For reindeer herdsmen, the welfare of their herd is important. Unstressed and relaxed reindeer that continue a normal ruminating and feeding cycle within their grazing gardens will have better meat taste and quality when slaughtered [36, 37]. We found 
TABLe 6: Results from model selection on restless behaviour among domestic wild animals using the AIC criterion (Np is number of parameters).

\begin{tabular}{|c|c|c|c|c|c|c|c|c|c|c|c|c|c|c|c|c|}
\hline $\begin{array}{l}\overrightarrow{0} \\
\overline{0} \\
\dot{\Sigma}\end{array}$ & 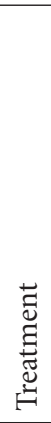 & $\widehat{\widehat{\oplus}}$ & 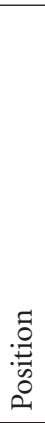 & 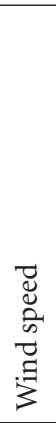 & 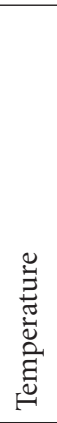 & 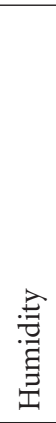 & 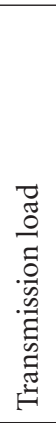 & 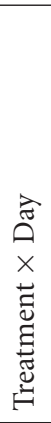 & 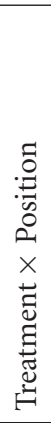 & 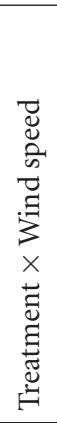 & 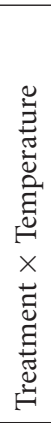 & 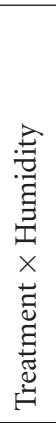 & 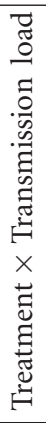 & $\mathrm{Np}$ & $\triangle \mathrm{AIC}$ & AIC weight \\
\hline 1 & & & & & & & & & & & & & & 3 & 33.2 & 0.00000 \\
\hline 2 & $\mathrm{x}$ & & & & & & & & & & & & & 4 & 35.2 & 0.00000 \\
\hline 3 & $\mathrm{x}$ & $\mathrm{x}$ & & & & & & & & & & & & 5 & 24.1 & 0.00001 \\
\hline 4 & $\mathrm{x}$ & & $\mathrm{x}$ & & & & & & & & & & & 7 & 16.3 & 0.00027 \\
\hline 5 & $\mathrm{x}$ & & & $\mathrm{x}$ & & & & & & & & & & 5 & 32.8 & 0.00000 \\
\hline 6 & $\mathrm{x}$ & & & & $\mathrm{x}$ & & & & & & & & & 5 & 36.8 & 0.00000 \\
\hline 7 & $\mathrm{x}$ & & & & & $\mathrm{x}$ & & & & & & & & 5 & 36.9 & 0.00000 \\
\hline 8 & $\mathrm{x}$ & & & & & & $\mathrm{x}$ & & & & & & & 5 & 37.2 & 0.00000 \\
\hline 9 & $\mathrm{x}$ & $\mathrm{x}$ & & & & & & $\mathrm{x}$ & & & & & & 6 & 18.9 & 0.00007 \\
\hline 10 & $\mathrm{x}$ & & $\mathrm{x}$ & & & & & & $\mathrm{x}$ & & & & & 10 & 16.5 & 0.00025 \\
\hline 11 & $\mathrm{x}$ & & & $\mathrm{x}$ & & & & & & $\mathrm{x}$ & & & & 6 & 34.7 & 0.00000 \\
\hline 12 & $\mathrm{x}$ & & & & $\mathrm{x}$ & & & & & & $\mathrm{x}$ & & & 6 & 38.8 & 0.00000 \\
\hline 13 & $\mathrm{x}$ & & & & & $\mathrm{x}$ & & & & & & $\mathrm{x}$ & & 6 & 38.4 & 0.00000 \\
\hline 14 & $\mathrm{x}$ & & & & & & $\mathrm{x}$ & & & & & & $\mathrm{x}$ & 6 & 39.2 & 0.00000 \\
\hline 15 & $\mathrm{x}$ & $\mathrm{x}$ & $\mathrm{x}$ & & & & & & & & & & & 8 & 11.0 & 0.00384 \\
\hline 16 & $\mathrm{x}$ & & $\mathrm{x}$ & $\mathrm{x}$ & & & & & & & & & & 8 & 14.1 & 0.00082 \\
\hline 17 & $\mathrm{x}$ & $\mathrm{x}$ & $\mathrm{x}$ & $\mathrm{x}$ & & & & & & & & & & 9 & 7.10 & 0.02702 \\
\hline 18 & $\mathrm{x}$ & $\mathrm{x}$ & $\mathrm{x}$ & $\mathrm{x}$ & & & & $\mathrm{x}$ & & & & & & 10 & 0.00 & 0.94068 \\
\hline 19 & $\mathrm{x}$ & $\mathrm{x}$ & $\mathrm{x}$ & $\mathrm{x}$ & & & & & $\mathrm{x}$ & & & & & 12 & 8.10 & 0.01639 \\
\hline 20 & $\mathrm{x}$ & $\mathrm{x}$ & $\mathrm{x}$ & $\mathrm{x}$ & & & & & & $\mathrm{x}$ & & & & 10 & 9.10 & 0.00994 \\
\hline
\end{tabular}

that the effect of the power lines on restless behaviour was ambiguous, with marginally more restless behaviour in the treatment enclosures for the domestic tame reindeer throughout the study period. This effect was significant, but the effect is very small and seems not relevant from a biological point of view. Restless behaviour increased with decreasing distance to the upper part of enclosures during both trials (Table 2), but since this effect was present in both control and treatment enclosures, it remains difficult to exclude an effect from the observation tower located near zone 2. The model suggests that, among the domestic wild animals, treatment animals showed a constant proportion of restless behaviour throughout the duration of the experiment, while the control animals increased their restless behaviour during the same period (Figure 3, Table 2). The change over time among domestic tame animals was significant, but with similar effects on both treatment and control. Therefore we find no clear signs of habituation to the power lines as an initial disturbance. In contrast to the domestic wild reindeer, domestic tame reindeer were more accustomed to enclosures and human handling from earlier experience. This difference is clearly reflected in a three times higher level of restless behaviour among the domestic wild than the domestic tame reindeer. Thus, in terms of domestic reindeers' restlessness within grazing gardens, past experience and different handling practices amongst different reindeer herding districts appear to be more important influential factors than the existence of a power line in the vicinity of or crossing a grazing garden.

There was a tendency, yet nonsignificant, for higher frequencies of activity changes in the treatment enclosures for both types of reindeer. The rate of activity changes may be positively correlated with the level of restless behaviour [17] and can provide an estimate of vigilant behaviour by recording short disruptions when a reindeer scans its surroundings for danger [38, 39]. If an initial disturbance effect from the power lines was present, we expected that habituation would normalise the behaviour in the treatment enclosures towards the later days of the experiment, but this was not the case. We suppose that there might be alternative, yet undisclosed, causes to the observed differences in activity changes between the treatment and control enclosures. In a similar designed study with the treatment being exposure to a windmill, we found no effects on animal behaviour between 
TABLE 7: Results from model selection on number of activity changes/minute among domestic tame animals using the AIC criterion (Np is number of parameters).

\begin{tabular}{|c|c|c|c|c|c|c|c|c|c|c|c|c|c|c|c|c|}
\hline 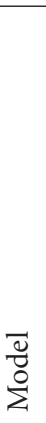 & 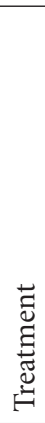 & $\overrightarrow{\tilde{A}}$ & 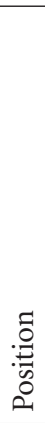 & 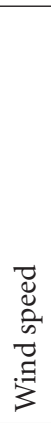 & 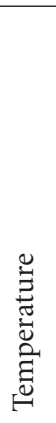 & 离 & 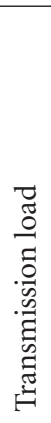 & 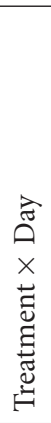 & 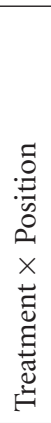 & 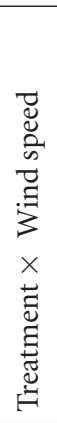 & 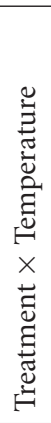 & 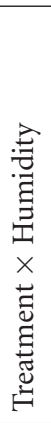 & 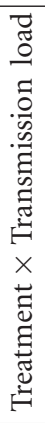 & $\mathrm{Np}$ & $\triangle \mathrm{AIC}$ & AIC weight \\
\hline 1 & & & & & & & & & & & & & & 3 & 3.14 & 0.02507 \\
\hline 2 & $\mathrm{x}$ & & & & & & & & & & & & & 4 & 0.91 & 0.07645 \\
\hline 3 & $\mathrm{x}$ & $\mathrm{x}$ & & & & & & & & & & & & 5 & 2.86 & 0.02883 \\
\hline 4 & $\mathrm{x}$ & & $\mathrm{x}$ & & & & & & & & & & & 5 & 1.50 & 0.05692 \\
\hline 5 & $\mathrm{x}$ & & & $\mathrm{x}$ & & & & & & & & & & 5 & 2.64 & 0.03219 \\
\hline 6 & $\mathrm{x}$ & & & & $\mathrm{x}$ & & & & & & & & & 5 & 1.26 & 0.06417 \\
\hline 7 & $\mathrm{x}$ & & & & & $\mathrm{x}$ & & & & & & & & 5 & 2.58 & 0.03317 \\
\hline 8 & $\mathrm{x}$ & & & & & & $\mathrm{x}$ & & & & & & & 5 & 1.86 & 0.04754 \\
\hline 9 & $\mathrm{x}$ & $\mathrm{x}$ & & & & & & $\mathrm{x}$ & & & & & & 6 & 4.85 & 0.01066 \\
\hline 10 & $\mathrm{x}$ & & $\mathrm{x}$ & & & & & & $\mathrm{x}$ & & & & & 6 & 3.15 & 0.02494 \\
\hline 11 & $\mathrm{x}$ & & & $\mathrm{x}$ & & & & & & $\mathrm{x}$ & & & & 6 & 4.55 & 0.01239 \\
\hline 12 & $\mathrm{x}$ & & & & $\mathrm{x}$ & & & & & & $\mathrm{x}$ & & & 6 & 2.53 & 0.03401 \\
\hline 13 & $\mathrm{x}$ & & & & & $\mathrm{x}$ & & & & & & $\mathrm{x}$ & & 6 & 4.12 & 0.01536 \\
\hline 14 & $\mathrm{x}$ & & & & & & $\mathrm{x}$ & & & & & & $\mathrm{x}$ & 6 & 0.00 & 0.12049 \\
\hline 15 & $\mathrm{x}$ & $\mathrm{x}$ & & & & & $\mathrm{x}$ & & & & & & $\mathrm{x}$ & 7 & 1.06 & 0.07092 \\
\hline 16 & $\mathrm{x}$ & & $\mathrm{x}$ & & & & $\mathrm{x}$ & & & & & & $\mathrm{x}$ & 7 & 0.87 & 0.07799 \\
\hline 17 & $\mathrm{x}$ & & & $\mathrm{x}$ & & & $\mathrm{x}$ & & & & & & $\mathrm{x}$ & 7 & 2.01 & 0.04411 \\
\hline 18 & $\mathrm{x}$ & & & & $\mathrm{x}$ & & $\mathrm{x}$ & & & & & & $\mathrm{x}$ & 7 & 1.14 & 0.06814 \\
\hline 19 & $\mathrm{x}$ & & & & & $\mathrm{x}$ & $\mathrm{x}$ & & & & & & $\mathrm{x}$ & 7 & 1.30 & 0.06290 \\
\hline
\end{tabular}

treatment and control enclosures [29]. It is not expected that power lines have a stronger effect on reindeers' frequencies of activity changes than a windmill, since a rotating windmill is more visually dominant and generates more noise.

4.3. Electromagnetic Fields and Noise from the Power Lines. It has been suggested that possible negative effects of power lines on animals are related to electric and/or magnetic fields, wind turbulent noise, corona noise, or induced vibrations in iron/steel constructions [11, 40]. Magnetic and electric fields from power lines are inversely proportional to the square of the distance from the conductor [41], and consequently, we expect that the fields in the power line enclosures were negligible outside zone 1. Our results suggest no effect of transmission load on behaviour since the domestic tame reindeer showed an increased proportion of restless behaviour with increasing level of transmission load in both control and treatment enclosures (Table 2). The magnetic field beneath a power line will not exceed $200 \mu \mathrm{T}$, while the threshold of human perception is $>5 \mathrm{mT}$ [41]. We assumed that reindeer were equally unable to sense the magnetic field beneath a power line, an assumption that may be challenged by two recent papers by Begall et al. [42] and Burda et al. [43] who report that resting and grazing cattle, red deer (Cervus elaphus), and roe deer (Capreolus capreolus) tended to align their body axes in the geomagnetic North-South direction, but that extremely low-frequency magnetic fields generated by high-voltage power lines disrupted this alignment. It should be noted that there has been a rather extensive discussion on magnetic alignment of ruminants and a possible role of other factors like wind, sun, and terrain conditions published in Nature (see http://www.nature.com/news/2008/080825/ful/news.2008 .1059.html). An e-mail discussion with special reference to Begall et al. [42] and Burda et al. [43] was followed up in the Animal Navigation Group with the Royal Institute of Navigation (March and April 2009). On the other hand, the presence of an electric field may be perceived by animals through stimulation of skin or hair. Some people can detect electric fields as gentle vibrations of hair on their head or their outstretched arm [11,41]. In their review, Algers and Hennichs [44] found that several species of mammals are able to perceive electric fields, varying in threshold of perception from $3.5 \mathrm{kV} / \mathrm{m}$ for mice Muridae spp. to $30 \mathrm{kV} / \mathrm{m}$ for swine Sus scrofa. The electric field $18 \mathrm{~m}$ underneath parallel 125 and $300 \mathrm{kV}$ power lines has been measured at a 
TABLE 8: Results from model selection on number of activity changes/minute among domestic wild animals using the AIC criterion (Np is number of parameters).

\begin{tabular}{|c|c|c|c|c|c|c|c|c|c|c|c|c|c|c|c|c|}
\hline $\begin{array}{l}\vec{D} \\
\stackrel{0}{0} \\
\Sigma\end{array}$ & 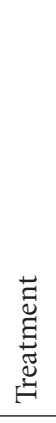 & ڤે & $\begin{array}{l}\stackrel{ే}{0} \\
: \stackrel{0}{0} \\
0 \\
0\end{array}$ & 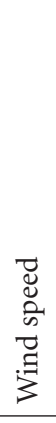 & 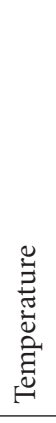 & 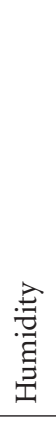 & 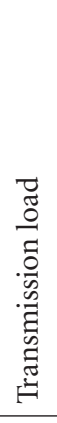 & 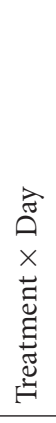 & 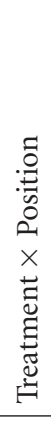 & 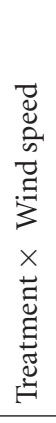 & 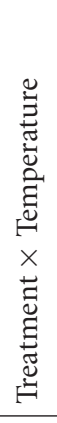 & 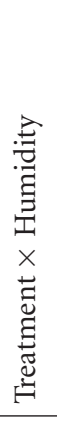 & 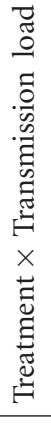 & $\mathrm{Np}$ & $\triangle \mathrm{AIC}$ & AIC weight \\
\hline 1 & & & & & & & & & & & & & & 3 & 26.63 & 0.00000 \\
\hline 2 & $\mathrm{x}$ & & & & & & & & & & & & & 4 & 26.33 & 0.00000 \\
\hline 3 & $\mathrm{x}$ & $\mathrm{x}$ & & & & & & & & & & & & 5 & 28.04 & 0.00000 \\
\hline 4 & $\mathrm{x}$ & & $\mathrm{x}$ & & & & & & & & & & & 5 & 18.15 & 0.00003 \\
\hline 5 & $\mathrm{x}$ & & & $\mathrm{x}$ & & & & & & & & & & 5 & 28.32 & 0.00000 \\
\hline 6 & $\mathrm{x}$ & & & & $\mathrm{x}$ & & & & & & & & & 5 & 6.95 & 0.00801 \\
\hline 7 & $\mathrm{x}$ & & & & & $\mathrm{x}$ & & & & & & & & 5 & 23.23 & 0.00000 \\
\hline 8 & $\mathrm{x}$ & & & & & & $\mathrm{x}$ & & & & & & & 5 & 26.46 & 0.00000 \\
\hline 9 & $\mathrm{x}$ & $\mathrm{x}$ & & & & & & $\mathrm{x}$ & & & & & & 6 & 29.97 & 0.00000 \\
\hline 10 & $\mathrm{x}$ & & $\mathrm{x}$ & & & & & & $\mathrm{x}$ & & & & & 6 & 19.32 & 0.00002 \\
\hline 11 & $\mathrm{x}$ & & & $\mathrm{x}$ & & & & & & $\mathrm{x}$ & & & & 6 & 29.74 & 0.00000 \\
\hline 12 & $\mathrm{x}$ & & & & $\mathrm{x}$ & & & & & & $\mathrm{x}$ & & & 6 & 7.830 & 0.00516 \\
\hline 13 & $\mathrm{x}$ & & & & & $\mathrm{x}$ & & & & & & $\mathrm{x}$ & & 6 & 24.89 & 0.00000 \\
\hline 14 & $\mathrm{x}$ & & & & & & $\mathrm{x}$ & & & & & & $\mathrm{x}$ & 6 & 25.02 & 0.00000 \\
\hline 15 & $\mathrm{x}$ & $\mathrm{x}$ & & & $\mathrm{x}$ & & & & & & & & & 6 & 6.260 & 0.01131 \\
\hline 16 & $\mathrm{x}$ & & $\mathrm{x}$ & & $\mathrm{x}$ & & & & & & & & & 6 & 1.540 & 0.11975 \\
\hline 17 & $\mathrm{x}$ & & & $\mathrm{x}$ & $\mathrm{x}$ & & & & & & & & & 6 & 8.330 & 0.00402 \\
\hline 18 & $\mathrm{x}$ & & & & $\mathrm{x}$ & $\mathrm{x}$ & & & & & & & & 6 & 8.380 & 0.00392 \\
\hline 19 & $\mathrm{x}$ & & & & $\mathrm{x}$ & & $\mathrm{x}$ & & & & & & & 6 & 8.940 & 0.00296 \\
\hline 20 & $\mathrm{x}$ & $\mathrm{x}$ & $\mathrm{x}$ & & $\mathrm{x}$ & & & & & & & & & 7 & 0.000 & 0.25863 \\
\hline 21 & $\mathrm{x}$ & & $\mathrm{x}$ & $\mathrm{x}$ & $\mathrm{x}$ & & & & & & & & & 7 & 3.030 & 0.05685 \\
\hline 22 & $\mathrm{x}$ & & $\mathrm{x}$ & & $\mathrm{x}$ & $\mathrm{x}$ & & & & & & & & 7 & 3.230 & 0.05144 \\
\hline 23 & $\mathrm{x}$ & & $\mathrm{x}$ & & $\mathrm{x}$ & & $\mathrm{x}$ & & & & & & & 7 & 3.530 & 0.04427 \\
\hline 24 & $\mathrm{x}$ & $\mathrm{x}$ & $\mathrm{x}$ & & $\mathrm{x}$ & & & $\mathrm{x}$ & & & & & & 8 & 1.990 & 0.09562 \\
\hline 25 & $\mathrm{x}$ & $\mathrm{x}$ & $\mathrm{x}$ & & $\mathrm{x}$ & & & & $\mathrm{x}$ & & & & & 8 & 0.740 & 0.17865 \\
\hline 26 & $\mathrm{x}$ & $\mathrm{x}$ & $\mathrm{x}$ & & $\mathrm{x}$ & & & & & & $\mathrm{x}$ & & & 8 & 1.020 & 0.15531 \\
\hline
\end{tabular}

TABLE 9: Results from model selection on space use (proportion use of lower half of enclosure) among domestic tame animals using the AIC criterion ( $\mathrm{Np}$ is number of parameters).

\begin{tabular}{|c|c|c|c|c|c|c|c|c|}
\hline Model & Treatment & Day & Transmission load & Treatment $\times$ Day & Treatment $\times$ Transmission load & $\mathrm{Np}$ & $\triangle \mathrm{AIC}$ & AIC weight \\
\hline 1 & & & & & & 3 & 78.8 & 0.00000 \\
\hline 2 & $\mathrm{x}$ & & & & & 4 & 75.7 & 0.00000 \\
\hline 3 & $\mathrm{x}$ & $\mathrm{x}$ & & & & 5 & 71.9 & 0.00000 \\
\hline 4 & $\mathrm{x}$ & & $\mathrm{x}$ & & & 5 & 50.3 & 0.00000 \\
\hline 5 & $\mathrm{x}$ & $\mathrm{x}$ & $\mathrm{x}$ & & & 6 & 32.2 & 0.00000 \\
\hline 6 & $\mathrm{x}$ & $\mathrm{x}$ & $\mathrm{x}$ & $\mathrm{x}$ & & 7 & 0.00 & 0.67918 \\
\hline 7 & $\mathrm{x}$ & $\mathrm{x}$ & $\mathrm{x}$ & & $\mathrm{x}$ & 7 & 26.9 & 0.00000 \\
\hline 8 & $\mathrm{x}$ & $\mathrm{x}$ & $\mathrm{x}$ & $\mathrm{x}$ & $\mathrm{x}$ & 8 & 1.50 & 0.32082 \\
\hline
\end{tabular}


TABLE 10: Results from model selection on space use (proportion use of lower half of enclosure) among domestic wild animals using the $\mathrm{AIC}$ criterion ( $\mathrm{Np}$ is number of parameters).

\begin{tabular}{|c|c|c|c|c|c|c|c|c|}
\hline Model & Treatment & Day & Transmission load & Treatment $\times$ Day & Treatment $\times$ Transmission load & $\mathrm{Np}$ & $\triangle \mathrm{AIC}$ & AIC weight \\
\hline 1 & & & & & & 3 & 211.1 & 0.00000 \\
\hline 2 & $\mathrm{x}$ & & & & & 4 & 210.5 & 0.00000 \\
\hline 3 & $\mathrm{x}$ & $\mathrm{x}$ & & & & 5 & 37.90 & 0.00000 \\
\hline 4 & $\mathrm{x}$ & & $\mathrm{x}$ & & & 5 & 202.9 & 0.00000 \\
\hline 5 & $\mathrm{x}$ & $\mathrm{x}$ & $\mathrm{x}$ & & & 6 & 36.60 & 0.00000 \\
\hline 6 & $\mathrm{x}$ & $\mathrm{x}$ & $\mathrm{x}$ & $\mathrm{x}$ & & 7 & 0.000 & 0.66819 \\
\hline 7 & $\mathrm{x}$ & $\mathrm{x}$ & $\mathrm{x}$ & & $\mathrm{x}$ & 7 & 37.30 & 0.00000 \\
\hline 8 & $\mathrm{x}$ & $\mathrm{x}$ & & $\mathrm{x}$ & & 6 & 1.400 & 0.33181 \\
\hline
\end{tabular}

maximum of $1.5 \mathrm{kV} / \mathrm{m}$ [45]. Since we do not know the exact threshold for reindeer, we cannot reject the possibility that they were able to sense the electric field of the $300 \mathrm{kV}$ power line in our treatment enclosures. However, the magnitude of the electric field depends on the voltage, and not the transmission load of the power line, and any effect on animal behaviour should not vary with transmission load. Increased noise from corona at higher transmission load remains a possibility, but overall dry, clear weather during the experimental period made it difficult to test specifically for effects of corona noise, which is related to electrical discharges in moist weather $[46,47]$. The model selection showed that ambient relative humidity could not explain much of the observed behaviour patterns (Tabels 5-8). Corona noise is different from naturally appearing noises in reindeer habitats, and the frequency of corona noise is audible by reindeer $[48,49]$. Furthermore, it may appear at times with low background noise (moist conditions and no wind). Some studies have shown short-time behavioural and physiological responses in reindeer when exposed to human activities of high noise intensity like petroleum exploration [50] and overflights by low-altitude jet-aircrafts and helicopters [51-53]. In contrast to such noise, corona noise from power lines is relatively continuous and predictable, but it is possible that the unfamiliarity of the corona noise may frighten reindeer. Further studies are needed to reveal this.

Wind speed varied and reached a peak of $18.7 \mathrm{~m} / \mathrm{s}$ (onehour average) during the experiment. Turbulent noise from the lines was often substantial from our subjective point of view. Restless behaviour decreased or was constant for both domestic tame and domestic wild animals with increasing wind speed indicating no disturbing effect from wind and associated noise from power lines and masts. Clearly, windrelated noise in Norwegian mountain areas common, and at high wind speed the background noise will mask much of the turbulent noise from lines and masts [48, 49].

4.4. Temperature and Insects. Insects, specifically warble flies (Hypoderma tarandi), nose bot flies (Cephenemyia trompe) and species of mosquitoes (Aedes spp., culicidae), horse flies (Family Tabanidae), and black flies (Family Simuliidae) influence Rangifer behaviour and may amplify or decrease response thresholds in relation to human activities [5456]. Our study took place in autumn with generally low levels of insect harassment, even on the warmest days. Restless behaviour in domestic tame reindeer increased with increasing temperature, probably due to increased levels of insect harassment $[17,30]$. This is in accordance with other studies [34, 57], where insect harassment had a strong impact on the activity budgets of caribou Rangifer tarandus in studies of disturbance from the Prudhoe Bay oilfields in Alaska. Contrary to domestic tame animals, we found no effect of temperature on restless behaviour in domestic wild animals possibly due to a generally high level of restless behaviour that may have masked a temperature effect. Furthermore, there was a decrease in rate of activity changes with increasing temperature for domestic wild reindeer, opposite of what we expected. Since this experimental trial was conducted later in the autumn, the general insect abundance might have been lower, although temperature ranges were equal to the first trial. The observed pattern might therefore merely be an artefact of the higher level of general restlessness amongst these reindeer.

4.5. Direct Effects of Power Lines on Ungulates in General. Studies of power lines showing direct negative effects on animal behaviour are few. In a review, Lee and Reiner [11] concluded that utility operating experience and results of research indicate that power line electric fields generally have no noticeable effects on livestock behaviour or health, but reported one study on cattle that may indicate adverse effects on behaviour and area use. The cattle increased their use of pasture underneath an $1100 \mathrm{kV}$ prototype power line when it was periodically de-energized [12]. Elk Cervus canadensis and sika deer Cervus nippon used power line corridors extensively for feeding $[9,10]$. This implies that possible negative effects of the lines are exceeded by the positive effects of browsing on early succession stages of deciduous forest that are prevalent in the power line corridor [58]. Studies on effects of power lines on ungulates in forested areas may not be relevant when evaluating effects on reindeer, since vegetation underneath power lines in mountain areas does not differ from the surroundings. Contrary to previous studies reporting strong aversion effects of power lines [46], this study and the study by Reimers et al. [8] indicated that power lines did not have strong direct negative effects on behaviour or area use when reindeer are held in a grazing garden or when free-ranging. 
Our experiment indicated that power lines were not a strong enough negative stimuli to induce semi-domesticated yearling female reindeer to avoid areas underneath the lines when enclosed in an area with maximum distance $<350 \mathrm{~m}$ from the lines. Using replicated treatment and control enclosures and by using two "types" of reindeer in separate trials, we were able to isolate and test for potential effects of the animals' past experience. For domestic reindeer, the animals' general level of "tameness", encompassing past experience with handling and confinement, influenced the animals' restlessness within a grazing garden more than the existence of a power line. For reindeer held in grazing gardens, and possibly for free ranging reindeer within $350 \mathrm{~m}$ from a power line, strong negative effects of power lines on pasture use, activity cycles, or energy budgets are unlikely.

\section{Acknowledgments}

The authors thank Rolf Sørumgård for assistance in planning, construction, and housing, Lesja Heimrast for area allowance, and Mathis A. Gaup and Vågå tamreinlag/Steinar Håkenstad for providing the reindeer. They are also indebted to Kim Abel, Pål Abrahamsen, Sindre Eftestøl, Ruben Eidesen, Jens Engan, Finn Gregersen, Bodhild Rekkedal, Jan Rune Samuelsen, Rune Stenseth, and Robert Sørlie for all assistance during field work, Professor Ørnulf Borgan for advice on the statistical analyses, Georg Thommesen for comments on the manuscript, and Svanøy Stiftelse/Trygve Solheim for providing video equipment. Funding was provided by the REIN-project under the EFFECT-programme (Norwegian Research Council contract no. 125127/212) and the Norwegian Research Council contract no. 154020/720. The study was carried out in compliance with Norwegian laws on the ethical treatment of animals used in experiments and research. They thank two anonymous referees for valuable comments to an earlier draft.

\section{References}

[1] S. M. Murphy and J. A. Curatolo, "Activity budgets and movement rates of caribou encountering pipelines, roads, and traffic in Northern Alaska," Canadian Journal of Zoology, vol. 65, no. 10, pp. 2483-2490, 1987.

[2] S. A. Wolfe, B. Griffith, and C. A. G. Wolfe, "Response of reindeer and caribou to human activities," Polar Research, vol. 19, no. 1, pp. 63-73, 2000.

[3] I. Vistnes, C. Nellemann, P. Jordhøy, and O. Strand, "Wild reindeer: impacts of progressive infrastructure development on distribution and range use," Polar Biology, vol. 24, no. 7, pp. 531-537, 2001.

[4] I. Vistnes and C. Nellemann, "Avoidance of cabins, roads, and power lines by reindeer during calving," Journal of Wildlife Management, vol. 65, no. 4, pp. 915-925, 2001.

[5] I. Vistnes, C. Nellemann, P. Jordhøy, and O. Strand, "Effects of infrastructure on migration and range use of wild reindeer," Journal of Wildlife Management, vol. 68, no. 1, pp. 101-108, 2004.

[6] C. Nellemann, I. Vistnes, P. Jordhoy, and O. Strand, "Winter distribution of wild reindeer in relation to power lines, roads and resorts," Biological Conservation, vol. 101, no. 3, pp. 351360, 2001.

[7] C. Nellemann, I. Vistnes, P. Jordhøy, O. Strand, and A. Newton, "Progressive impact of piecemeal infrastructure development on wild reindeer," Biological Conservation, vol. 113, no. 2, pp. 307-317, 2003.

[8] E. Reimers, B. Dahle, S. Eftestøl, J. E. Colman, and E. Gaare, "Effects of a power line on migration and range use of wild reindeer," Biological Conservation, vol. 134, no. 4, pp. 484-494, 2007.

[9] J. G. J. Goodwin, Big Game Movement Near a 500-kV Transmission Line in Northern Idaho, Bonneville Power Administration, Engineering and Construction Division, Portland, Ore, USA, 1975.

[10] S. Takatsuki, "A case study on the effects of a transmission-line corridor on Sika deer habitat use at the foothills of Mt Goyo, northern Honshu, Japan," Ecological Research, vol. 7, no. 2, pp. 141-146, 1992.

[11] J. M. J. Lee and G. L. Reiner, "Transmission line electric fields and the possible effects on livestock and honeybees," Transactions of the ASAE, vol. 26, pp. 279-286, 1983.

[12] L. E. Rogers, J. L. Warren, N. R. Hinds, K. A. Gano, R. E. Fitzner, and G. F. Piepel, "Environmental studies of a 1100$\mathrm{kV}$ prototype transmission line, an annual report for the 1981 study period," Transactions of the ASAE, vol. 25, pp. 279-286, 1982.

[13] E. Reimers and J. E. Colman, "Reindeer and caribou (Rangifer) response to human activity," Rangifer, vol. 26, pp. 55-71, 2006.

[14] E. Reimers, Rein og menneskelig aktivitet: en litteraturstudie, NVE-Vassdragsdirektoratet, Natur- og Landskapsavdelingen, Oslo, Norway, 1986.

[15] C. Nellemann and R. D. Cameron, "Cumulative impacts of an evolving oil-field complex on the distribution of calving caribou," Canadian Journal of Zoology, vol. 76, no. 8, pp. 14251430, 1998.

[16] J. Altman, "Observational study of behavior: sampling methods," Behaviour, vol. 49, pp. 227-267, 1974.

[17] F. M. Mörschel and D. R. Klein, "Effects of weather and parasitic insects on behavior and group dynamics of caribou of the Delta Herd, Alaska," Canadian Journal of Zoology, vol. 75, no. 10, pp. 1659-1670, 1997.

[18] J. E. Colman, C. Pedersen, D. Ø. Hjermann, Ø. Holand, S. R. Moe, and E. Reimers, "Twenty-four-hour feeding and lying patterns of wild reindeer Rangifer tarandus tarandus in summer," Canadian Journal of Zoology, vol. 79, no. 12, pp. 2168-2175, 2001.

[19] J. E. Colman, C. Pedersen, D. Ø. Hjermann, Ø. Holand, S. R. Moe, and E. Reimers, "Do wild reindeer exhibit grazing compensation during insect harassment?" Journal of Wildlife Management, vol. 67, no. 1, pp. 11-19, 2003.

[20] M. O. Hill, DECORANA-A Fortran Program for Detrended Correspondence Analysis and Reciprocal Averaging, Cornell University, Ithaca, NY, USA, 1979.

[21] R. Sørlie, Ectomycorrhiza on Salix herbacea L. in the glacier foreland of Midtdalsbreen, Finse, Norway, M.S. thesis, University of Oslo, Oslo, Norway, 2001.

[22] C. S. Gillies, M. Hebblewhite, S. E. Nielsen, et al., "Application of random effects to the study of resource selection by animals," Journal of Animal Ecology, vol. 75, no. 4, pp. 887898, 2006.

[23] J. C. Pinheiro and D. M. Bates, Mixed-Effects Models in S and S-PLUS, Springer, New York, NY, USA, 2000. 
[24] R. D. C. Team, R: A Language and Environment for Statistical Computing, R Foundation for Statistical Computing, Vienna, Austria, 2005.

[25] D. Bates, "Fitting linear mixed models," R.R. News, vol. 5, pp. 27-30, 2005.

[26] H. Akaike, "A new look at statistical model identification," IEEE Transactions on Automatic Control, vol. 19, pp. 716-723, 1974.

[27] T. Skogland, Villrein-Fra Urinnvåner til Miljøbarometer, Teknologisk, Oslo, Norway, 1994.

[28] J. E. Colman, Behaviour patterns of wild reindeer in relation to sheep and parasitic flies, Ph.D. thesis, University of Oslo, Oslo, Norway, 2000.

[29] K. Flydal, S. Eftestøl, E. Reimers, and J. E. Colman, "Effects of wind turbines on area use and behaviour of semidomesticated reindeer in enclosures," Rangifer, vol. 24, pp. 5566, 2004.

[30] R. I. M. Hagemoen and E. Reimers, "Reindeer summer activity pattern in relation to weather and insect harassment," Journal of Animal Ecology, vol. 71, no. 5, pp. 883-892, 2002.

[31] K. P. Burnham and D. R. Anderson, Model Selection and Multimodel Inference-A Practical Information-Theoretic Approach, Springer, New York, NY, USA, 2002.

[32] E. Reimers, "Activity pattern; the major determinant for growth and fattening in Rangifer?" in Second International Reindeer/Caribou Symposium, Røros, Norway, 1979, E. Reimers, E. Gaare, and S. Skjenneberg, Eds., pp. 466-474, Direktoratet for Vilt og Ferskvannsfisk, Trondheim, Norway, 1980.

[33] J. Trudell and R. G. White, "The effect of forage structure and availability on food intake, biting rate, bite size and daily eating time of reindeer," Journal of Applied Ecology, vol. 18, pp. 63-81, 1981.

[34] S. M. Murphy and J. A. Curatolo, "Activity budgets and movement rates of caribou encountering pipelines, roads, and traffic in northern Alaska," Canadian Journal of Zoology, vol. 65, no. 10, pp. 2483-2490, 1987.

[35] C. J. A. Bradshaw, S. Boutin, and D. M. Hebert, "Energetic implications of disturbance caused by petroleum exploration to woodland caribou," Canadian Journal of Zoology, vol. 76, no. 7, pp. 1319-1324, 1998.

[36] E. Wiklund, A. Andersson, G. Malmfors, and K. Lundström, "Muscle glycogen levels and blood metabolites in reindeer (Rangifer tarandus tarandus L.) after transport and lairage," Meat Science, vol. 42, no. 2, pp. 133-144, 1996.

[37] E. Wiklund, L. Johansson, and G. Malmfors, "Sensory meat quality, ultimate $\mathrm{pH}$ values, blood parameters and carcass characteristics in reindeer (Rangifer tarandus tarandus L.) grazed on natural pastures or fed a commercial feed mixture," Food Quality and Preference, vol. 14, no. 7, pp. 573-581, 2003.

[38] P. S. Bøving and E. Post, "Vigilance and foraging behaviour of female caribou in relation to predation risk," Rangifer, vol. 17, pp. 55-63, 1997.

[39] E. Reimers and S. Svela, "Vigilance behaviour in wild reindeer and semi-domestic reindeer in Norway," Alces, vol. 37, pp. 1$11,2002$.

[40] J. M. J. Lee and D. B. Griffith, “Transmission line audible noise and wildlife," in Effects of Noise on Wildlife, J. L. Fletcher and R. G. Busnel, Eds., pp. 105-168, Academic Press, London, UK, 1978.

[41] B. J. Maddock, Electric Power Transmission and the Environment: Fields, Noise, and Interference, National Grid Research and Development Centre, Letterhead, UK, 1990.
[42] S. Begall, J. Červený, J. Neef, O. Vojtěch, and H. Burda, "Magnetic alignment in grazing and resting cattle and deer," Proceedings of the National Academy of Sciences of the United States of America, vol. 105, no. 36, pp. 13451-13455, 2008.

[43] H. Burda, S. Begall, J. Červený, J. Neef, and P. Němec, "Extremely low-frequency electromagnetic fields disrupt magnetic alignment of ruminants," Proceedings of the National Academy of Sciences of the United States of America, vol. 106, no. 14, pp. 5708-5713, 2009.

[44] B. Algers and K. Hennichs, "Biological effects of electromagnetic fields on vertebrates. A review," Veterinary Research Communications, vol. 6, no. 1, pp. 265-279, 1983.

[45] M. Waskaas, Elektriske felt i høyspenningsanlegg, Statens Institutt for Strålevern, Oslo, Norway, 1982.

[46] M. G. Comber and L. E. Zaffanella, "Audible noise," in Transmission Line Reference Book $345 \mathrm{kV}$ and Above, pp. 192238, Electric Power Research Institute, Palo Alto, Calif, USA, 1975.

[47] Z. Engel and T. Wszolłek, "Audible noise of transmission lines caused by the corona effect: analysis, modelling, prediction," Applied Acoustics, vol. 47, no. 2, pp. 149-163, 1996.

[48] K. Flydal, A. Hermansen, P. S. Enger, and E. Reimers, "Hearing in reindeer (Rangifer tarandus)," Journal of Comparative Physiology A, vol. 187, no. 4, pp. 265-269, 2001.

[49] K. Flydal, I. R. Kilde, P. S. Enger, and E. Reimers, "Reindeer (Rangifer tarandus tarandus) perception of noise from power lines," Rangifer, vol. 23, pp. 21-24, 2003.

[50] C. J. A. Bradshaw, S. Boutin, and D. M. Hebert, "Effects of petroleum exploration on woodland caribou in northeastern Alberta," Journal of Wildlife Management, vol. 61, no. 4, pp. 1127-1133, 1997.

[51] F. Berntsen, Reinens reaksjon på lavtflyvende luftfartøy, NINA Oppdragsmelding no. 390, Norsk Institutt for Naturforskning, Trondheim, Norway, 1996.

[52] F. H. Harrington and A. M. Veitch, "Short-term impacts of low-level jet fighter training on caribou in Labrador," Arctic, vol. 44, no. 4, pp. 318-327, 1991.

[53] J. A. K. Maier, S. M. Murphy, R. G. White, and M. D. Smith, "Responses of caribou to overflights by low-altitude jet aircraft," Journal of Wildlife Management, vol. 62, supplement 2, pp. 752-766, 1998.

[54] J. A. Curatolo and S. M. Murphy, "The effects of pipelines, roads, and traffic on the movement of caribou, Rangifer tarandus," Canadian Field-Naturalist, vol. 100, pp. 218-224, 1986.

[55] L. E. Noel, R. H. Pollard, W. B. Ballard, and M. A. Cronin, "Activity and use of active gravel pads and tundra by caribou, Rangifer tarandus granti, within the Prudhoe Bay oil field, Alaska," Canadian Field-Naturalist, vol. 112, no. 3, pp. 400409, 1998.

[56] R. H. Pollard, W. B. Ballard, L. E. Noel, and M. A. Cronin, "Parasitic insect abundance and microclimate of gravel pads and tundra within the Prudhoe Bay oil field, Alaska, in relation to use by caribou, Rangifer tarandus granti," Canadian FieldNaturalist, vol. 110, no. 4, pp. 649-658, 1996.

[57] S. G. Fancy, "Movements and activity budgets of caribou near oil drilling sites in the Sagavanirktok river floodplain, Alaska," Arctic, vol. 36, pp. 193-197, 1983.

[58] R. L. Jefferies, D. R. Klein, and G. R. Shaver, "Vertebrate herbivores and northern plant communities: reciprocal influences and responses," Oikos, vol. 71, no. 2, pp. 193-206, 1994. 

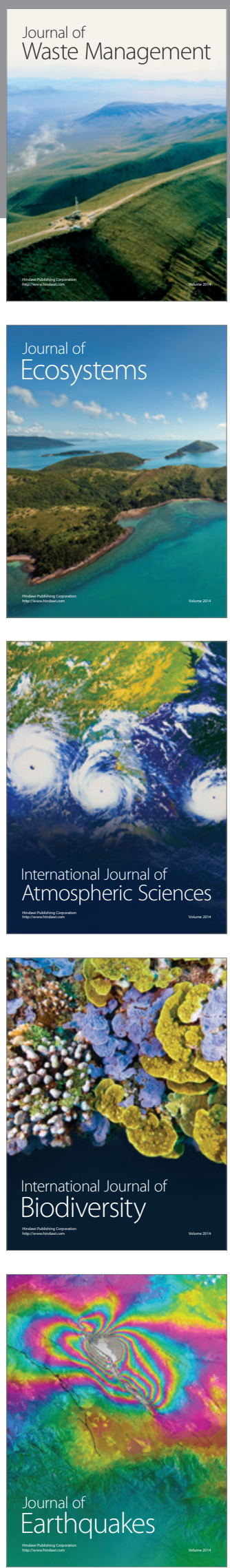
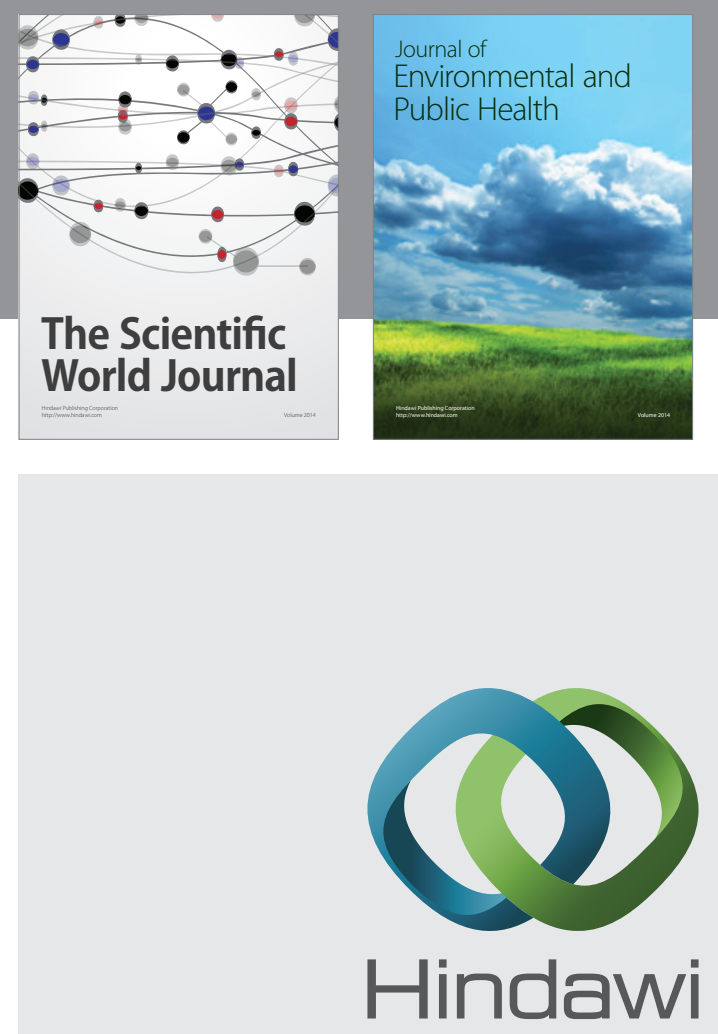

Submit your manuscripts at

http://www.hindawi.com
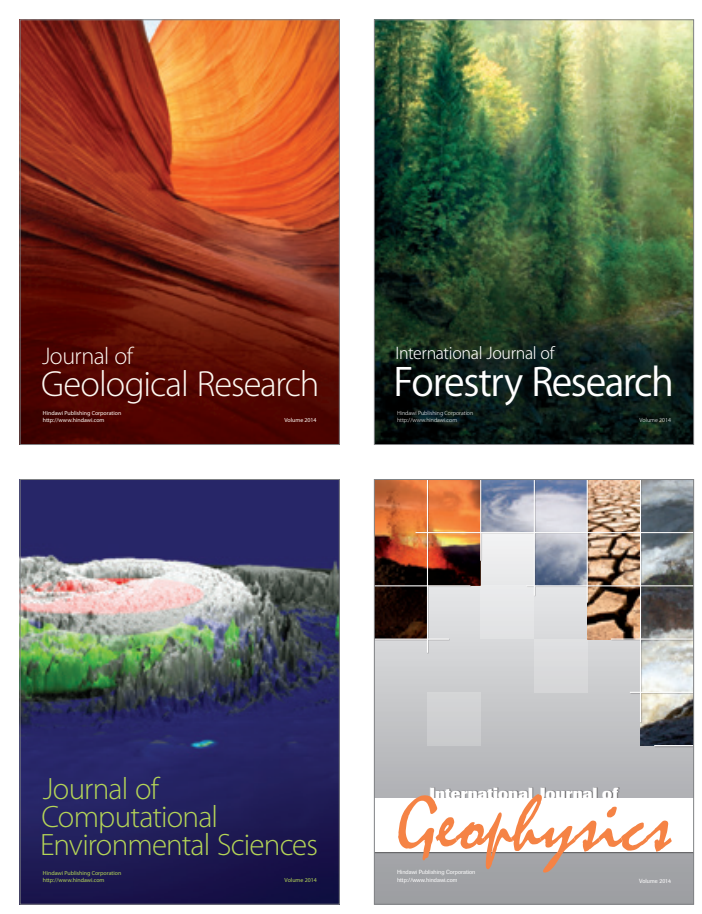
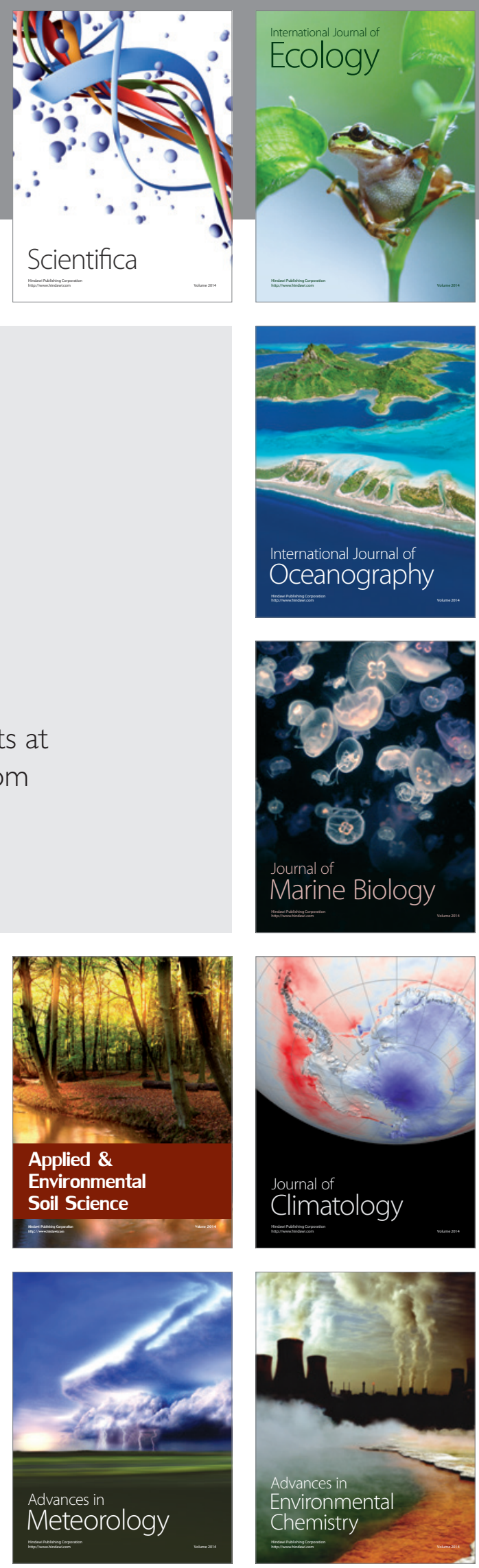